\title{
The Use of WhatsApp on Political Marketing Agenda in Malaysia Politics
}

\section{Mohd Azmir Mohd Nizah, Afi Roshezry Abu Bakar}

To Link this Article: http://dx.doi.org/10.6007/IJARBSS/v11-i8/10626

DOI:10.6007/IJARBSS/v11-i8/10626

Received: 08 June 2021, Revised: 10 July 2021, Accepted: 28 July 2021

Published Online: 24 August 2021

In-Text Citation: (Nizah \& Bakar, 2021)

To Cite this Article: Nizah, M. A. M., \& Bakar, A. R. A. (2021). The Use of WhatsApp on Political Marketing Agenda in Malaysia Politics. International Journal of Academic Research in Business and Social Sciences, 11(8), 1660-1677.

\section{Copyright: @ 2021 The Author(s)}

Published by Human Resource Management Academic Research Society (www.hrmars.com)

This article is published under the Creative Commons Attribution (CC BY 4.0) license. Anyone may reproduce, distribute, translate and create derivative works of this article (for both commercial and non-commercial purposes), subject to full attribution to the original publication and authors. The full terms of this license may be seen at: http://creativecommons.org/licences/by/4.0/legalcode

Vol. 11, No. 8, 2021, Pg. 1660 - 1677

Full Terms \& Conditions of access and use can be found at http://hrmars.com/index.php/pages/detail/publication-ethics 


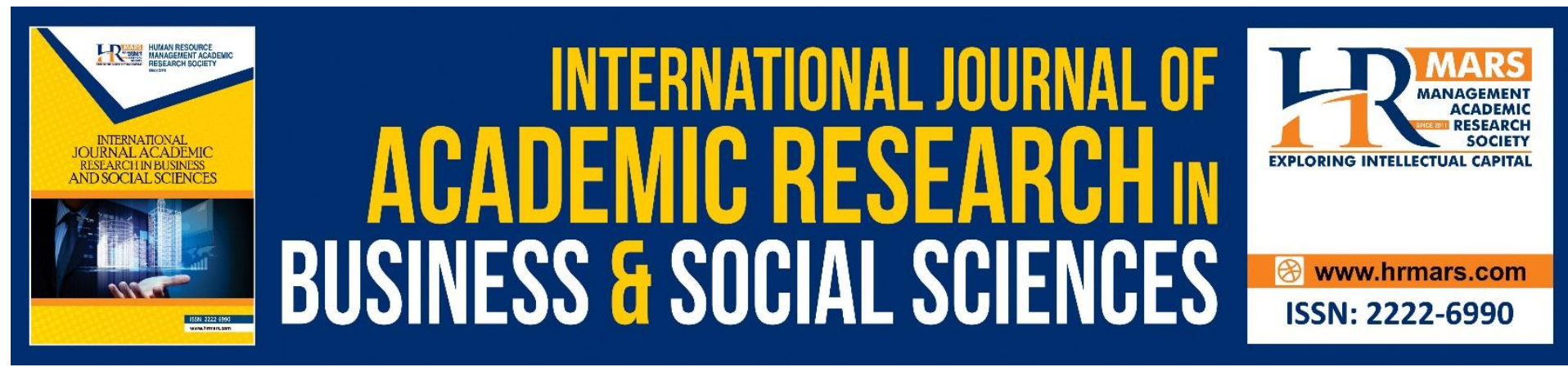

\title{
The Use of WhatsApp on Political Marketing Agenda in Malaysia Politics
}

\author{
Mohd Azmir Mohd Nizah \\ Centre for Core Studies \& Faculty of Leadership \& Management, Universiti Sains Islam \\ Malaysia, Bandar Baru Nilai, 71800, Negeri Sembilan, Malaysia \\ Email: azmirnizah@usim.edu.my \\ Afi Roshezry Abu Bakar \\ Department of Journalism, Universiti Tunku Abdul Rahman, Kampar Campus, 31900 \\ Kampar, Perak, Malaysia
}

\begin{abstract}
A historic event was created in Malaysia when Pakatan Harapan, the then opposition party, won Malaysia's 14th general election. Doubted as "the father of all elections" as it evidenced the collapse of 60 years of Barisan Nasional ruling era. For Pakatan Harapan, it is beyond their wildest dream. This article aims to explain how WhatsApp plays a major factor in influencing voters to make their decision. It also aims to analyze how WhatsApp assisted users in accessing information, using the information, and disseminating political party and campaigning agenda in political marketing strategies. Using content analysis and a simple random survey involving 406 respondents, this study found that WhatsApp political and agenda-setting content plays a significant role compared to other social media and instant messaging services in Malaysia. Accessibility and handy usage become the factor in accessing information, use the information and then disseminate political campaigning content, thus assisted political marketing agenda. Future use of WhatsApp on political marketing agenda is eminent and worth for future studies.
\end{abstract}

Keywords: Social Media, Election, Political Behavior, Electoral Campaigning, Malaysia

\section{Introduction}

The 14th Malaysian General Election (GE14) has created a major event in Malaysia's political and electoral history so far. The results are beyond the wildest dream. Barisan Nasional (BN), the longest governing party was defeated with 121 seats won by Pakatan Harapan (PH) that makes a simple majority, thus has the right to form a new government. It also witnessed that BN not only lost another five states to PH including Melaka, Negeri Sembilan, Johor, Kedah, and Sabah; but also lost in terms of popular votes into 32 percent only, while Terengganu falls onto Malaysian Islamic Party (Parti Islam Se-Malaysia or PAS). By far, it is the worst performance of BN, which comprised various political parties, mainly United Malays National Organization (UMNO), Malaysian Chinese Association (MCA), Malaysian Indian Congress (MIC), and its components parties. Malaysia also chronicled few historic events including the 
changing of government in most democratic ways through the electoral process without any violent events. It also exhibited that Tun Dr. Mahathir Mohamad, a former Prime Minister in 1981-2003, was re-elected as Prime Minister for the second time, making him the oldest Prime Minister in the world at the age of 94; which he then resigned due to domestic party issues in Mac 2020. Interestingly, his appointment was sanctioned by 71 percent of the young electorate aged between 21 to 49 years old.

As information and communication technology rapidly changes, so do the political marketing strategies and its tools. New media, which took stage approximately in 2003 with Myspace then followed by other social media and microblogging applications such as Facebook (2004); Twitter (2006); Instagram (2010) and the most popular is the WhatsApp (2009) application (Hamid \& Rahman, 2018). Social media such as Facebook, Twitter, Telegram, Youtube, Snapchat, WeChat users, and so on are normally used to share their views and opinions, diary-like activities, and blogging for and of personal interest. Because of its major contribution to persuasion, news related to political activities, views, and campaigning began to take place also. But its importance in setting political agenda is still missing (Gilardi et.al, 2021).

For instance, in the United States (US) presidential election in 2008, the then Barack Obama campaigned was considered as the benefactor of social media and microblogging movement in the use of information and communication technologies, which later emulated then by Donald Trump, though in radically fashioned, often with twitters bulldozed arguments (Boczkowski \& Papacharissi, 2018). It is recognized as the first US national campaign that used new media technologies and the internet (Al-Deen \& Hendricks, 2012). This has led to the social media revolution not only in the United States electoral campaign but also affected other countries such as Britain with Brexit Campaign, France with Yellow Jacket protestor, Hong Kong with pro-democracy movement, Egypt, Syria, Sudan, Zimbabwe, Brazil, Spain, and Ukraine including Malaysia's election scenery. This shift somehow does affect the Malaysian political landscape from the 2008 election until the 2018 general election, with young voters, do play a major influence (Zubaidah, 2009, p. 16). Patrice Victor one of the Reporters without Borders' regional correspond have mentioned that the Malaysian experience may help the other nations to replicate as they also develop a potent combination of repressive governments and better reasonable Internet access (Bose, 2011, p. 2).

In dissimilarity, some researchers report that social media such as Facebook, Twitter, Youtube, and others do not necessarily translate into electoral success (Larsson \& Moe, 2012; Leng Ho, 2012; Miller \& Ko, 2015) but its influence in forming protest behavior is salient (Jost et al., 2018; Poell, 2019). Nevertheless, social media contributing role in political information dissemination has been identified when BN lost two-thirds majority in the 2008 polls and continues declined in the 2013 election result (Azhar, 2013; Azmir Nizah, Abdul Azzis, \& Ibrahim, 2016; Weiss, 2013). Additionally, Instagram, Facebook, YouTube, and Twitter have considered an essential application for today's communication and news sources. It can be evidenced as this application was pre-installed in many smartphone brands that are available in the market. Smartphone producers and manufacturers also viewed this as a marketing strategy to appeal to users. A huge enterprise like Apple and Samsung which has been dominated the smartphone market for quite sometimes are facing stiff challenges by Chinaborn corporation like Huawei, Xiaomi, Oppo, Vivo, and few others (GSMArena.com, 2019). 


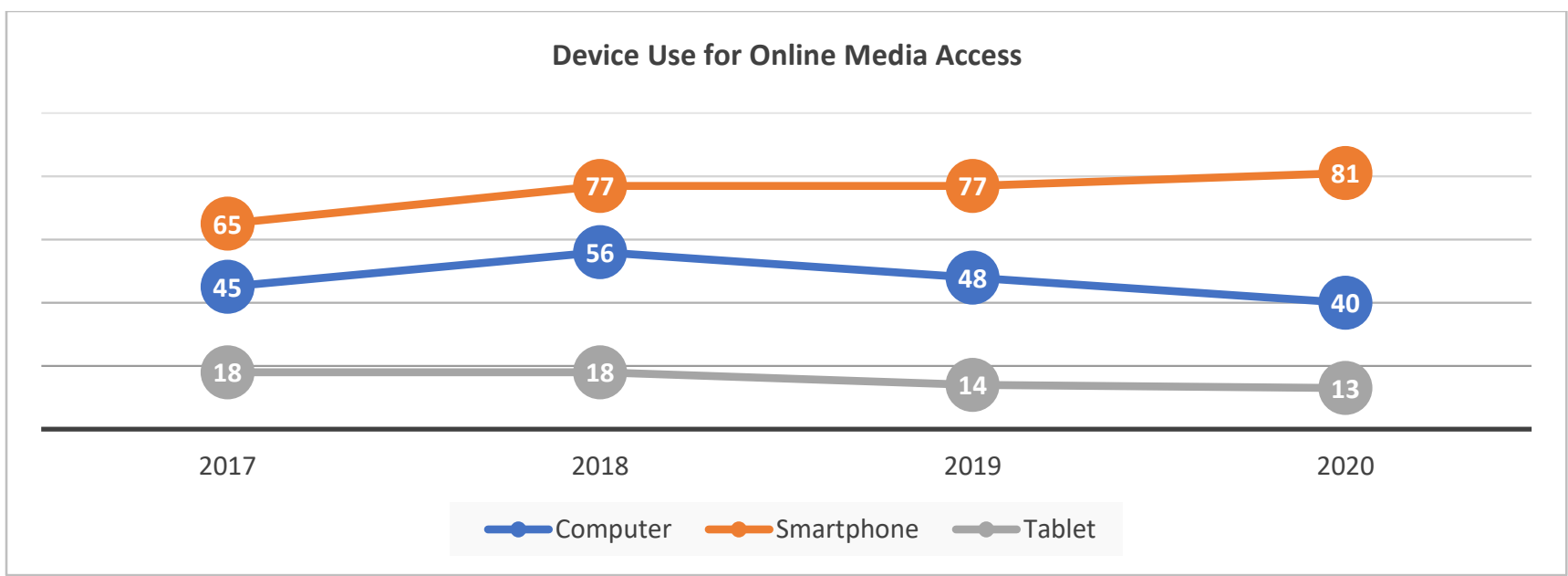

Figure 1 Device Use for Online News. Source: Reuters Institute Digital News Report 2021

The race for market acquisitions was attributed to the inclusiveness of social media available in their product. Users have these apps for their daily life activities, throwing opinions, and information gathering. Live update and streaming of events, photo sharing, voicing out their concerns and dissatisfaction and many more do contribute to the fastchanging of this application, and what more on its content carried. According to the study by Campbell and Kwak (2010), found that the usage of the mobile phone especially for information exchange was mainly associated with higher civic and also political engagement. It became interestingly, expressing opinions on political topics in Malaysia especially before or during the GE14 tremendously increased (Chinnasamy \& Abdul, 2018). Figure 1 Device Use for Online News depicts the different devices used for online access. It showed a constant change in the use of different forms of media. Print media have shown a negative trend for the past four years, while online including social media use showed a stable change.

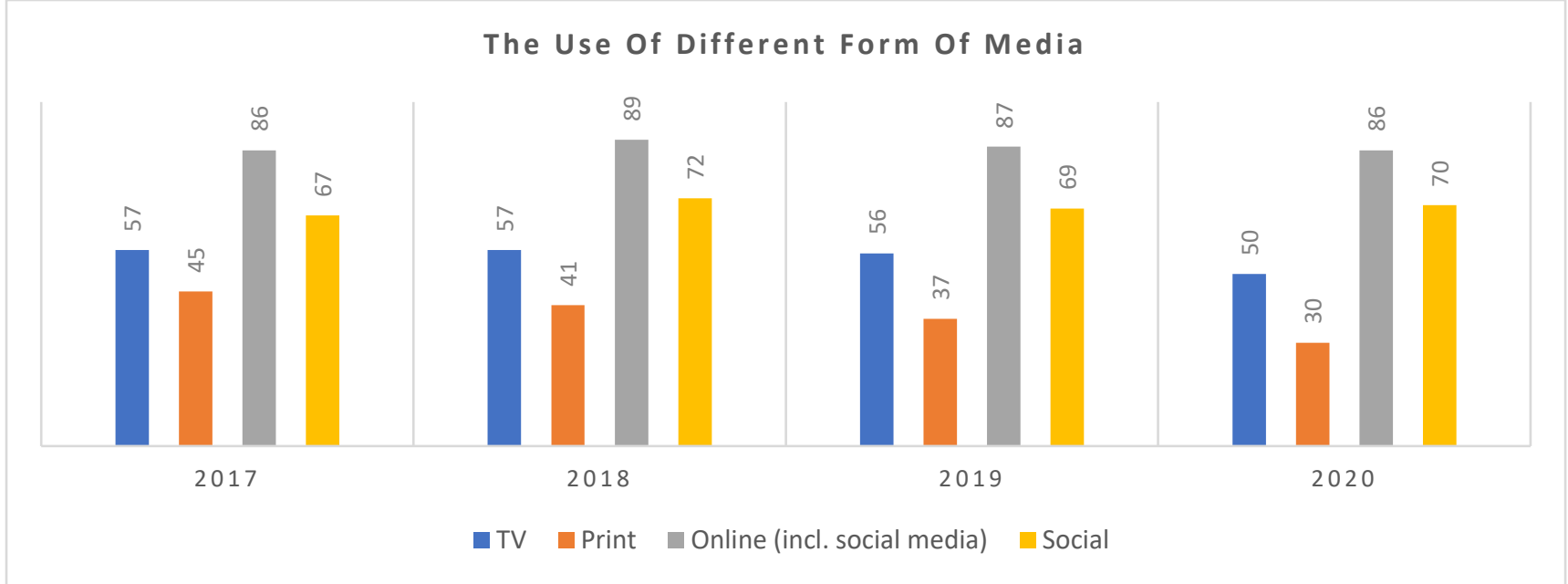

Figure 2 The Use of Different Forms of Media. Source: Reuters Institute Digital News Report 2021

Social media has been acknowledged as the major contributing factor for such a result in GE14 as evidenced in Figure 2. One of the ascertaining factors is the exponential growth of social media. In the year 2008, it is only 800000 Facebook users. The amount was then skyrocketing to 22 million in 2018 (Miniwatts Marketing Group, 2018). As of June 2021, it was reported that the number of registered users for Facebook is approximately 29 million 
(Internetworldstats.com, 2021). In terms of political views and topics, $18.3 \%$ of internet users shared their political views online. According to Statista Research Department, (2019), almost 18.4 million smartphones users in Malaysia, and forecasted more than 20 million in 2020 (Müller, 2021). It does confirm that the underpinning cause of the phenomenon is the smartphone penetration that energizes more users to access the Internet than ever (Abdul Wahab, 2016).

It does also due to the capacity of microblogging that supports blogging activity with smaller sizes of word posts and their user-friendly features that offer wide usage among millennials (Yusop \& Sumari, 2013). The emergence of the concept such as e-participation (Gibson \& Cantijoch, 2013; Grönlund \& Wakabi, 2015; Vicente \& Novo, 2014); cyber democracy (Chun \& Cho, 2012); digital democracy (Hyun, 2012); and also "Netizens" is another evidence on how important that the role of social media plays in Malaysia political participation. All these concepts essentially assuage the importance of the Internet as a tool during political campaigns especially in the recent 14th General Election in Malaysia. This situation paves for Instant Messaging (IM) application to plays a bigger role in political marketing tools for the sake of political campaigns effectively and comprehensively influence the voters.

WhatsApp, being the most popular mobile massaging app with 2 billion users worldwide (Statista Research Department, 2021). As for Malaysia, it is reported that 68 percent active users in daily activities and growing to 22 million users as of 2019 (Mobilesquared, 2019). Simple logic to this situation is due to the exponential factor that each smartphone users may at least have three different WhatsApp groups. Once information is received, the forwarding message may spiral into triplets. One of the great pieces of evidence was news in India spiral over 55 percents from its 340 million users, which creates serious concern in 2018 India Elections. The same goes with 2020 U.S Presidential Election (Clayton, 2020; Dave, 2020). Research conducted by Norshuhada Shiratuddin et al., (2016) points out that seven major social media tools used by the respondents (Generation Y), including WhatsApp, Facebook, Google+, YouTube, Instagram, and also Twitter. WhatsApp and Facebook are the most popular tools used by the respondents (Generation Y), where more than $50 \%$ of the total of 1029 respondents use them frequently. A report from Statista, We are Social and a few other research firms confirmed this trend, and it is most highly unlikely communication will be without WhatsApp.

Because most of the previous research very much focusing on the impact of Facebook (Chang \& Tham, 2016; Leng Ho, 2012) and Twitter (Faizal Kasmani, Sabran, \& Adzrah Ramle, 2014; Rosyidah Muhamad, 2015) on electoral results in Malaysia, this study, however, will discuss on the impact of WhatsApp on elections outcome. Therefore, this study is to embark on the influencing factor of WhatsApp in political marketing and party campaigning strategy in the wake of GE 14. A simple random survey was also conducted to confirm the exponential power of WhatsApp in assisting the political marketing agenda in Malaysia.

\section{Changing Dynamics}

Weiss (2013) regards Malaysia as a semi-democratic nation, whereby media was alleged to control by the previous regime through mainstream media either print, online, television, and outdoor advertisement. This was significantly giving to the growth of alternative media, such as blogs, news online media, and social media known as new media. This is due to anti-regime sentiment and presumed political liberalization (Pepinsky, 2013) perception among citizens. The steep decline of circulations of a mainstream newspaper such as Malay-language Berita 
Harian and Utusan Malaysia with 30 percent drop, while English-language newspaper New Straits Times suffered from 41.6 percent drop from 2012 (Audit Bureau of Circulations Malaysia, 2017; Zulkifli Sulong, 2017) become the evidence on how online news media is the other choice of Malaysian, at least those who are categorized as middle class and those in living in the urban and suburban areas (Nizah \& Bakar, 2019). This situation may also be further viewed and understand from the Freedom House and Reporter Without Borders reports as in Tables 1 and 2 .

Table 1 Index of Press Freedom in Malaysia (Freedom House)

\begin{tabular}{|c|c|c|c|c|c|c|c|c|c|c|c|c|}
\hline \multirow{4}{*}{ Index } & 200 & 200 & 201 & & & \multirow{4}{*}{2015} & \multirow{4}{*}{$\begin{array}{l}201 \\
6\end{array}$} & \multirow{4}{*}{$\begin{array}{l}201 \\
7\end{array}$} & \multirow{4}{*}{$\begin{array}{l}201 \\
8\end{array}$} & \multirow{4}{*}{$\begin{array}{l}201 \\
9\end{array}$} & \multirow{4}{*}{$\begin{array}{l}202 \\
0\end{array}$} & \multirow{4}{*}{$\begin{array}{l}202 \\
1\end{array}$} \\
\hline & 4- & 8- & $0-$ & 201 & 201 & & & & & & & \\
\hline & 200 & 200 & 201 & 2 & 4 & & & & & & & \\
\hline & 5 & 9 & 1 & & & & & & & & & \\
\hline $\begin{array}{l}\text { World } \\
\text { Rating }\end{array}$ & 69 & 65 & 64 & 63 & 64 & 65 & 67 & 69 & 45 & 52 & 52 & 51 \\
\hline $\begin{array}{l}\text { World } \\
\text { Rankin } \\
\text { g }\end{array}$ & $\begin{array}{l}154 t \\
h\end{array}$ & $\begin{array}{l}141 \\
\text { st }\end{array}$ & $\begin{array}{l}141 \\
\text { st }\end{array}$ & $\begin{array}{l}144 t \\
h\end{array}$ & $\begin{array}{l}141 \\
\text { st }\end{array}$ & $\begin{array}{l}142 n \\
d\end{array}$ & $\begin{array}{l}149 t \\
h\end{array}$ & $\begin{array}{l}151 \\
\text { st }\end{array}$ & \multicolumn{4}{|c|}{ Not available } \\
\hline $\begin{array}{l}\text { Press } \\
\text { Freedo } \\
\mathrm{m}\end{array}$ & $\begin{array}{l}\text { Not } \\
\text { Free }\end{array}$ & $\begin{array}{l}\text { Not } \\
\text { Free }\end{array}$ & $\begin{array}{l}\text { Not } \\
\text { Free }\end{array}$ & $\begin{array}{l}\text { Not } \\
\text { Free }\end{array}$ & $\begin{array}{l}\text { Not } \\
\text { Free }\end{array}$ & $\begin{array}{l}\text { Not } \\
\text { Free }\end{array}$ & $\begin{array}{l}\text { Not } \\
\text { Free }\end{array}$ & $\begin{array}{l}\text { Not } \\
\text { Free }\end{array}$ & $\begin{array}{l}\text { Partl } \\
\text { y } \\
\text { Free }\end{array}$ & $\begin{array}{l}\text { Partl } \\
\text { y } \\
\text { Free } \\
\end{array}$ & $\begin{array}{l}\text { Partl } \\
\text { y } \\
\text { Free }\end{array}$ & $\begin{array}{l}\text { Partl } \\
\text { y } \\
\text { Free }\end{array}$ \\
\hline
\end{tabular}

Source: www.freedomhouse.org Note: 0- Most Free, 100=Least Free

Table 1 evidenced the press freedom in Malaysia. This repercussion is based on the perception that mainstream media is either governing party-owned or state-owned business entity. However, the further decline in terms of world rating and world ranking should be addressed intensely by the newly sanctioned government, and the current government. Otherwise, the current government may put itself at risk in the next election times. Post GE 14, and with the political turmoil on March 2020 which led to the change elected government, the world ranking, and rating steadfastly change.

Table 2 Index of Press Freedom in Malaysia (Reporter without Borders)

\begin{tabular}{lllllllllllllllll}
\hline Index & 2004 & 2005 & 2006 & 2007 & 2008 & 2010 & 2012 & $\begin{array}{l}2013- \\
2015\end{array}$ & 2016 & 2017 & 2018 & 2019 & 2020 & 2021 \\
\hline $\begin{array}{l}\text { World } \\
\text { Score }\end{array}$ & 39.3 & 33 & 22.5 & 41 & 39.5 & 50.5 & 56 & 42.7 & 46.5 & 46.8 & 47.8 & 36.74 & 33.12 & 39.47 \\
\hline $\begin{array}{l}\text { World } \\
\text { Ranking }\end{array}$ & 122 th & 113 & 92 & 124 & 132 & 141 & 122 & 147 & 146 & 144 & 145 & 123 & 101 & 119 \\
\hline $\begin{array}{l}\text { Press } \\
\text { Freedom }\end{array}$ & Free & Nree & Free & Free & Free & Free & Free & Free & Free & Free & Free & Free & Free & Free \\
\hline
\end{tabular}

Source: www.rsf.org Note: 0-15- Good; 15.01-25: Fairly Good; 25.01-35: Problematic; 35.01-

55: Bad; 55.01-100: Very Bad

Because online news sites are not covered by the restrictive Printing Presses and Publications Act, thus these sites are deeming to be more independent and critical on political and public issues. Figure 3 and Figure 4 further given a remarkable indication of the 
INTERNATIONAL JOURNAL OF ACADEMIC RESEARCH IN BUSINESS AND SOCIAL SCIENCES Vol. 11, No. 8, 2021, E-ISSN: 2222-6990 @ 2021 HRMARS

penetration of news sites such as Malaysiakini, Berita Harian online, Bernama.com, and few others compared with offline news media.

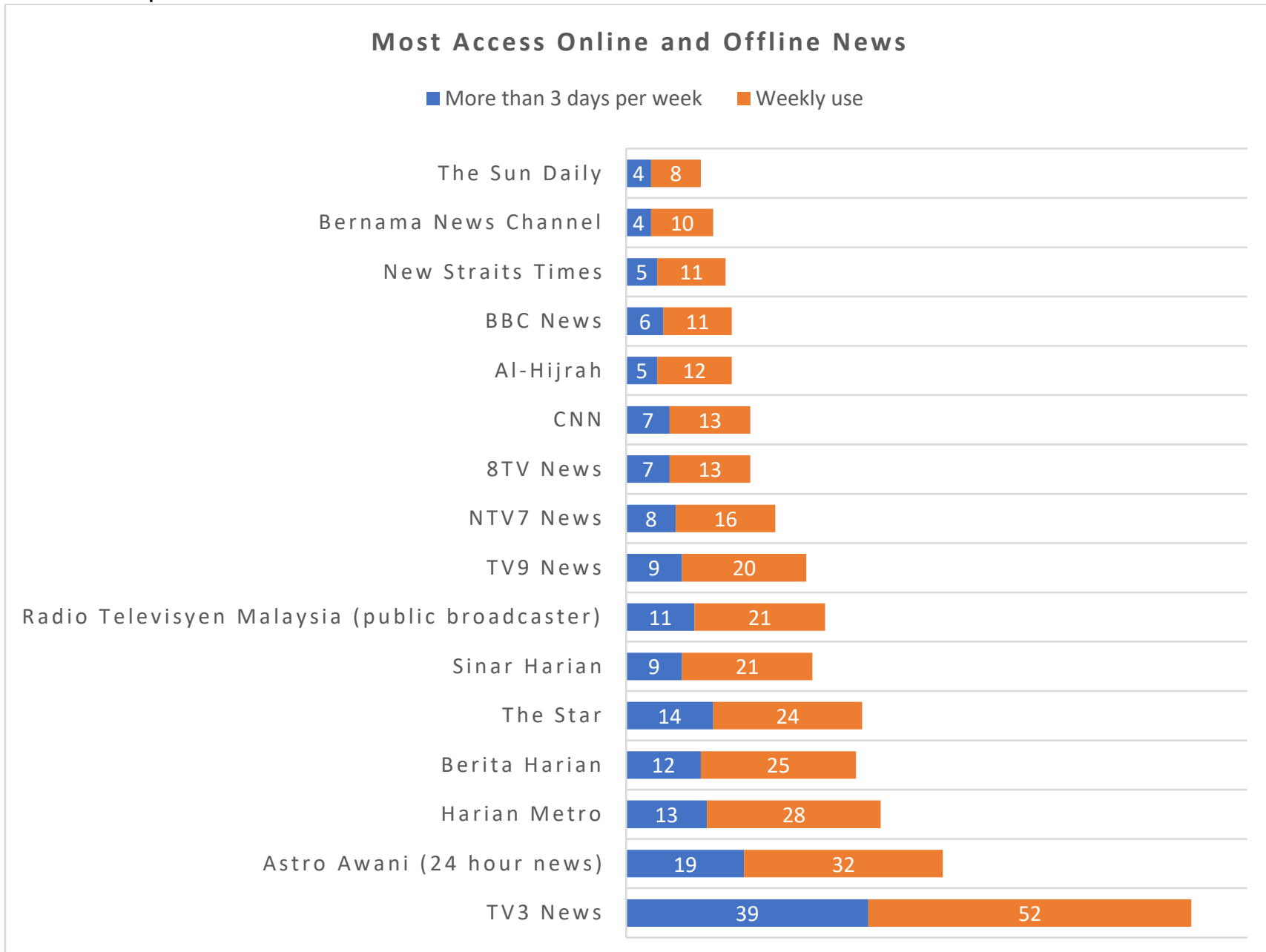

Figure 3 Most Access Online News Sites in 2020

\section{Most Access News Portal}

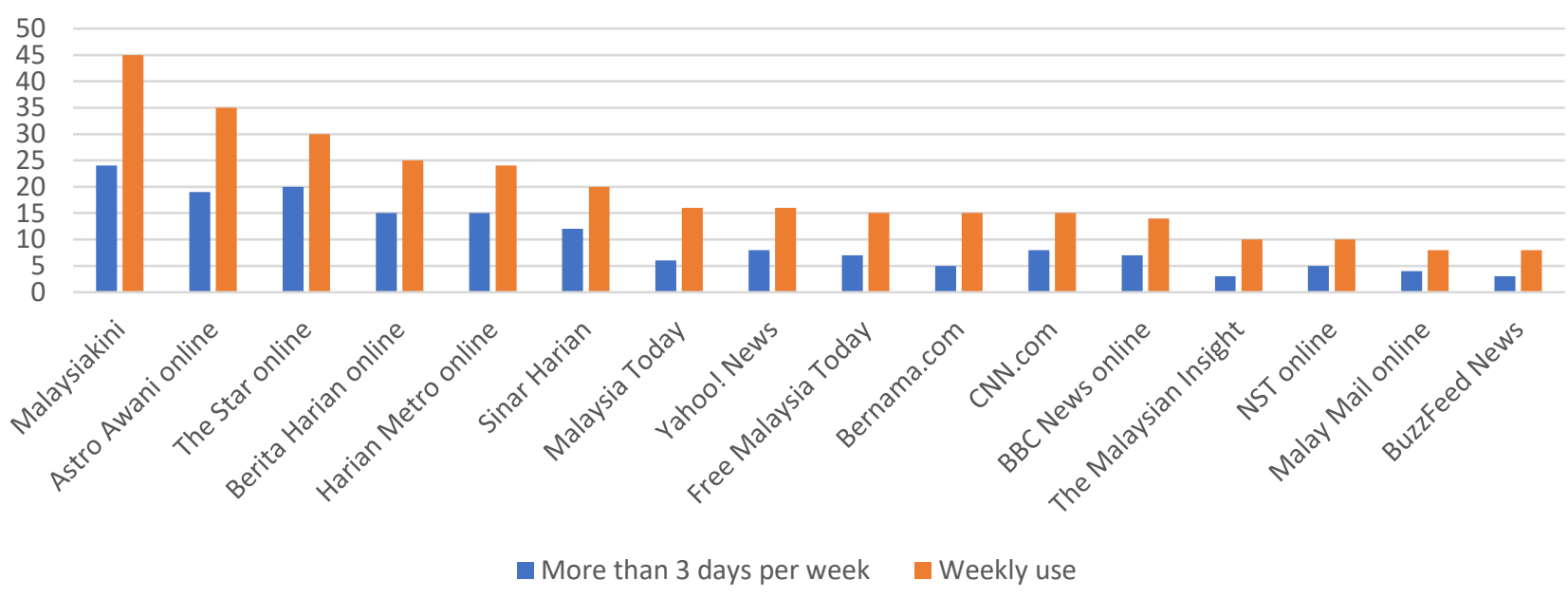

Figure 4 Most Access News Portal in 2020 
Reports on Reuters Institute for the Study of Journalism (Newman et al., 2017; Newman et al., 2021) found that an alternative online media has become the most visited page by Malaysian. It is deeming the medium of choice for mobile users which have been estimated 89.4 percent of Malaysian consumers as evidenced in Figure 1. Further analysis confirmed the trend that exists among Malaysians. The graph below showed that WhatsApp has been used heavily for other purposes and is second in news seeking.

The Use of Social Media

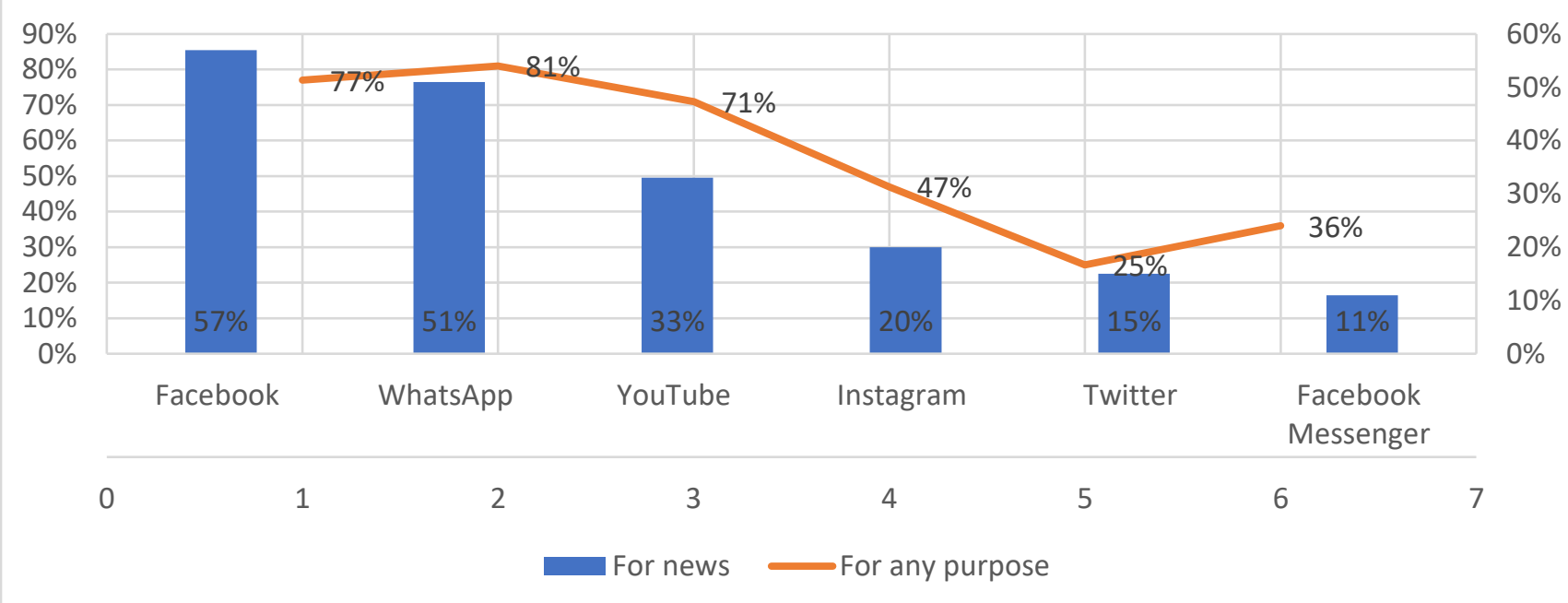

Figure 5 Top Social Media Use

In the 12th General Election (GE12) 2008, new media through blogs, party websites, Facebook, news portal, and Youtube has been credited as a source of information and political marketing for opposition to contrast a much widen pro-government mainstream media. Democratic Action Party (DAP) and BN established their Youtube channel in the wake of the 2008 election, while PAS created its channel in 2009. In terms of Facebook, only Parti Keadilan Rakyat (PKR) started its Facebook account after the 2008 general election. With regards to Twitter, Anwar Ibrahim was the only politician who had a Twitter account before the 2008 election. However, the above scenario tremendously changed with regards to social media as the 2013 general election approaching. The Malaysian Communications Multimedia Commission (MCMC) then declared on monitoring and controlling social media usage for any abuses and seditious postings to ensure GE13 is smooth and harmonious during the election (Bernama, 2013). It is evidenced by the utmost importance of BN to ensure the prescribed truth by controlling information to voters, and it also showed the importance of social media in electoral results. Even in the difficult environment, the opposition coalition known as Pakatan Rakyat (PR) or People's Alliance managed to capture 82 parliamentary seats, which then denied the two-third majority of BN. This led to most observers concluded that internet access and penetration become one of the contributing factors to the increasing victories of opposition parties in the GE12 election. Former Prime Minister, Tun Abdullah Ahmad Badawi then acknowledged BN's misjudgment of information and election campaigns which neglect the power of the internet and social media. Tun Abdullah Ahmad Badawi also admitted as the spreading growths of social media not only obtain greater openness but could be a doubleedged sword for his UMNO party.

It was the beginning era of the "Internet of things" and it was the most influential communication tool among urban, younger voters and internet savvy voters (Maznah, 2008). 
This sentiment was also shared by former Prime Minister Najib Tun Razak when he concluded that the 13th General election is the first social media election in Malaysia. Besides, Najib also sensed how essential social media is to young voters and this generation in the next general election. On 27 February 2013, after launching the Malaysia Social Media Week 2013 summit, Najib did emphasize the influence of social media may not be the biggest factor in the elections, but he admitted it is certainly increasing the tempo of the current political debate (Lim, 2013).

In the 13th General Election (GE13) 2013, the political landscape is changing steadily. In the wake of GE13, social media users have been increases multifold as compare to GE12. GE13 is also billed as "the mother of all elections" because it apexes to a "political tsunami". GE13 then showed extensive use of online videos to spread the message. Videos comprised of political rallies attendance, either overwhelming or serious lack of attendance, clips of parties and candidates, political parodies and satire, incidents occurred, scenes on nomination and polling day, and news reports are freely available and widespread to voters. Similarly, like GE12, in GE13, BN has muscled its political power and resources with posters, banners, and billboards along federal and state roads, so do as along highways. Reports estimate a total of RM264 million is spent on online marketing and advertising space (Zurairi, 2013) which is five times more than it did previously. The total expenditure for advertising blitz was 531 million as reported by international media buying agency Vizeum Media (Malay Mail, 2013).

As it turned out, BN's performance is worse than GE12 despite having spent a huge amount of money on advertising and online political marketing. BN's strategy on negative campaigning through its mainstream media, internet-based services, and social media did make PR went to extreme measures as portrays itself as a 'victim' and use social media as a counter-frame to BN muscled might. PR not only denying BN to its two-third majority but strengthen Selangor and Pulau Pinang legislative assembly seats instead. This may explain why BN lose miserably in GE13.

\section{Instant Messaging, Social Media Role, and GE 14's Electoral Outcome}

Despite probably spending a huge amount of money online and offline, to improve BN presence in the lead up for 14th General Election (GE14) in 2018, BN however could not measure the downward of voter's support. Scholars and political scientists often refuse to give their predictions in the wake of GE14. AWANI channel, a paid satellite television owned by All-Asian Satellite Television and Radio Operator (ASTRO) turned to be a second favorite news channel to TV3 News. TV3 News aired by the TV3 channel of Media Prima still top the ranking (Newman et al., 2017, 2021). As earlier reports confirmed, television is still a source of trust news in Malaysia (Zurairi, 2018) but it does not necessarily translate into votes. AWANI tends to portray it centralist as compared to RTM and TV3 that often portrays and perceived as BN and UMNO 'official news'. Slight changes occurred post GE14, with TV3 is making increments in terms of views as depicts in Figure 4 Most Access News Portal in 2020.

Given experience on GE13 and the impact shown by the online news portal, BN had launched a 'pop up' strategy in any online website, including the news portal. With 'tagline' Hebatkan Negaraku, BN expected it may lure more voters in achieving a new mandate in GE14. However, the GE14 results came out with the wildest opposition can dream about, with $\mathrm{PH}$ thumping BN both parliamentary seats and popular votes. Table 3 Comparative Results of Malaysia's General Election on 2013 and 2018 summarized comparative election results of GE13 and GE14. 
INTERNATIONAL JOURNAL OF ACADEMIC RESEARCH IN BUSINESS AND SOCIAL SCIENCES Vol. 11, No. 8, 2021, E-ISSN: 2222-6990 @ 2021 HRMARS

Table 3 Comparative Results of Malaysia's General Election on 2013 and 2018

\begin{tabular}{lll|lll}
\hline \multicolumn{7}{c}{ GE13 } & \multicolumn{3}{l}{ GE14 } \\
\hline Party Contested & $\begin{array}{l}\text { Barisan } \\
\text { Nasional } \\
\text { (BN) }\end{array}$ & $\begin{array}{l}\text { Pakatan } \\
\text { Rakyat } \\
(\text { PR) }\end{array}$ & $\begin{array}{l}\text { Barisan } \\
\text { Nasional } \\
\text { (BN) }\end{array}$ & $\begin{array}{l}\text { Pakatan } \\
\text { Harapan } \\
\text { (PR) }\end{array}$ & $\begin{array}{l}\text { Parti Islam } \\
\text { Se Malaysia } \\
\text { (PAS) }\end{array}$ \\
\hline $\begin{array}{l}\text { Parliamentary } \\
\text { Seats Won }\end{array}$ & 133 & 89 & 79 & 121 & 18 \\
\hline Votes Count & 53,66997 & 41,47014 & 40,78928 & 57,95954 & 20,39722 \\
\hline Votes Percentage & $48.55 \%$ & $37.51 \%$ & $33.35 \%$ & $47.39 \%$ & $16.69 \%$ \\
\hline Popular Votes & 52,37699 & 56,23984 & 37,94827 & 57,67390 & 19,33435 \\
\hline $\begin{array}{l}\text { Popular Votes } \\
\text { Percentage }\end{array}$ & $47.38 \%$ & $50.87 \%$ & $32 \%$ & $49.54 \%$ & $16 \%$ \\
\hline Retrievedfrom & & & & & \\
\hline
\end{tabular}

Retrieved from https://dashboard.spr.gov.my/pru14/\#!/home

However, understanding the contributing factors for such results is matters most. Domestic issues and scandals, party leadership, economic factors, and social media has been long regarded as contributing factors to voters in making their decision. However, due to higher internet penetration and social media usage, social media thus becoming the underneath enablers in casting a ballot. Previous research confirmed social media predictive power remains elusive (Gomez, 2014) overpower structure, incumbent advantage, access to resources, the politicization of ethnicity and Islam, and electoral irregularities, but GE14 results explain otherwise.

The power of social media is exceeded space and it is an efficient tool to reach out to first-time young voters who eschew the normal Malaysian campaign fare of rallies (Abdullah \& Anuar, 2018). Additionally, a study conducted by Pew Research Center (Lee Rainie et.al., 2012; Shirley, 2014) found that almost 25 percent of 2,253 political survey respondents in social media believe that debating, discussing or sharing views on political issues with other people on the social network is something "very important" or "quite important". According to Shiratuddin et al., (2016), all the views from the youth by using social media are desirably be recorded and must be considered before the government wants to take any action or taken in the development of the country. Apart from requesting their voices to be heard, they also want that social media as an important channel for public policy engagement and dealing with the government. It's to show how important social media is to play their role among the youth in the nowadays political environment.

Barisan Nasional remains the most popular choice among the poorest constituencies in Malaysia. Based on the statistics in the GE13 results showed that some $40 \%$ out of 79 parliamentary seats that Barisan had won in the general election are of the lowest median household income quartile- and consider the poorest $25 \%$ of constituencies (The Star Online, 2018). Data released by the Department of Statistics revealed that those in the lowest quartile are constituencies including Bagan Datuk, Mersing, and Baling, in which the median household incomes are between RM2, 208, and RM 3,612.

Moreover, Sani (2014) argued that roughly $60.7 \%$ of Malaysia are internet users in 2012 where there was a huge increase of $300 \%$ of internet penetration level in Malaysia since the election in 2008. In other views, Kemp (2012) reported that almost $90 \%$ of Malaysian Internet users have registered into social media accounts. Muniandy \& Muniandy (2013) then verified that Malaysian netizens view social network sites 14 billion times every month, with YouTube accounted for $67 \%$ of all online videos viewed in Malaysia. But in 2020, WhatsApp had leaped the trend. Despite the fact of false news spreading on these online platforms, 
social media is still one that political leaders used to upload their speech and activities for campaigning (Chinnasamy, 2018). In comparison to the olden days, campaigning was done through walking door-to-door meetings or wandering in the market to talk about themselves or party and even putting out the poster and waving flags, even rally talks are held at night to attract the crowd to them. The emergence of social media mainly WhatsApp and others created another dimension of the campaign by all the politicians and the political parties in the last general election. The Covid19 pandemic has made the change of political marketing even more rapid-paced.

In addition to that, WhatsApp is a tool that is effective to reach the crowd other than Facebook and Twitter, with its simple function of forwarding messages and even video, but it's also turned into a channel for fake news (Chu, 2018; Nizah \& Bakar, 2019). In fact, in this 14th election, messaging service WhatsApp is considered the most dominant and effective messaging tool to reach the audience. People easily get messages and videos on the election campaign almost every day and share with their friends, family, colleague, or even community chat groups. Nevertheless, the existence of the new media also as a result of the development of the internet has made the media a democratic agent of information (Salman et.al, 2018).

Since 2008, the use of new media began and setting a new way of campaigning to appeal to voters for competing parties. New media play a vital role as "public sentinels" by generating and publicizing information about the performance of government. Furthermore, it can be modeling the incentives of politicians to deliver, and making the governments more responsive to the voters; resulted in improving the quality of government public policies. New media also can become the platform to enable the efforts of civil societies to mobilize the citizens towards the anti-corruption movements and help the citizens to monitor the performance of the government of the day; and become the agent of "social accountability (Peruzzotti, Smulovitz, 2006). Informational uses of the internet and identified usage as a resource and a forum were associated with higher levels of civic engagement. Interactive civic messaging was often a stronger influence on civic engagement than traditional newspaper readership, television consumption, and face-to-face discussion around politics. This can be evidenced during GE14 with \#Hebatkan Negarku \#PulangUndi \#CarPoolGE14 social media campaign. The existence of these sites and portals created an alternative platform for the opposition during that period to penetrate and appeal the support from the public. Furthermore, all these sites and portals were contributory in persuasive the public especially the Malaysian urban middle class to turn against the Barisan Nasional ruling party and express their anger and vote protests for the opposition leaders.

According to Malaysian Communications and Multimedia Commission (2017) reports, signified that the highest internet penetration was in the Klang Valley area, the nation's capital, Kuala Lumpur, at $71 \%$, and increased to $88.7 \%$ (Malaysian Communications and Multimedia Commission, 2020). This is followed by the most developed state in Malaysia, that is, Selangor (71\%), and at the administrative capital, Putrajaya (89\%). As expected internet penetration is still relatively low in other less populated states such as Sabah (43\%) and Sarawak (41\%), situated in east Malaysia (Wok \& Mohamed, 2017).

While in 2013 the using of social media such as Facebook, and Twitter marks the trend and yet current in 2018 the using of WhatsApp has become more influential in keeping important political issues in the past few years and will become more significant in coming years ahead (Abdullah \& Anuar, 2018). Its shows how social media do make a huge impact on the citizens' civic engagement especially in news worldwide. These new media or social media have also enlarged the restrictive public sphere of traditional media, allowing more 
alternative voices and views to emerge. Furthermore, the usage of the internet which is the most commonly used of media in the 21st century have the strength to influence public opinion especially on the issues of politics and elections but may result in some biased situation, therefore affecting the voting trend in the end. Hence, social media can be said as a double-edged sword with its pros and cons. Internet poses very real potential threats to the healthy functions of representative democracy. As voters, always are mindful when it comes to the news related to politics no matter where the sources it comes whether from the newspaper, blogs, Facebook, Twitter, or other social media. It is in fact, the time for voters to be wise and get wise.

Through an online survey involving 185 male and 221 female respondents, it revealed that there was a slight difference in the form of social media used by the young respondents. It shows that female respondents used Facebook more than WhatsApp. Figure 6 and Figure 7 depicts the finding of the survey question on gender details and the usage of WhatsApp dan Facebook. 406 respondents are statistically beyond minimum acceptance of 384 of 100,000 population as suggested by (Krejcie \& Morgan, 1970).

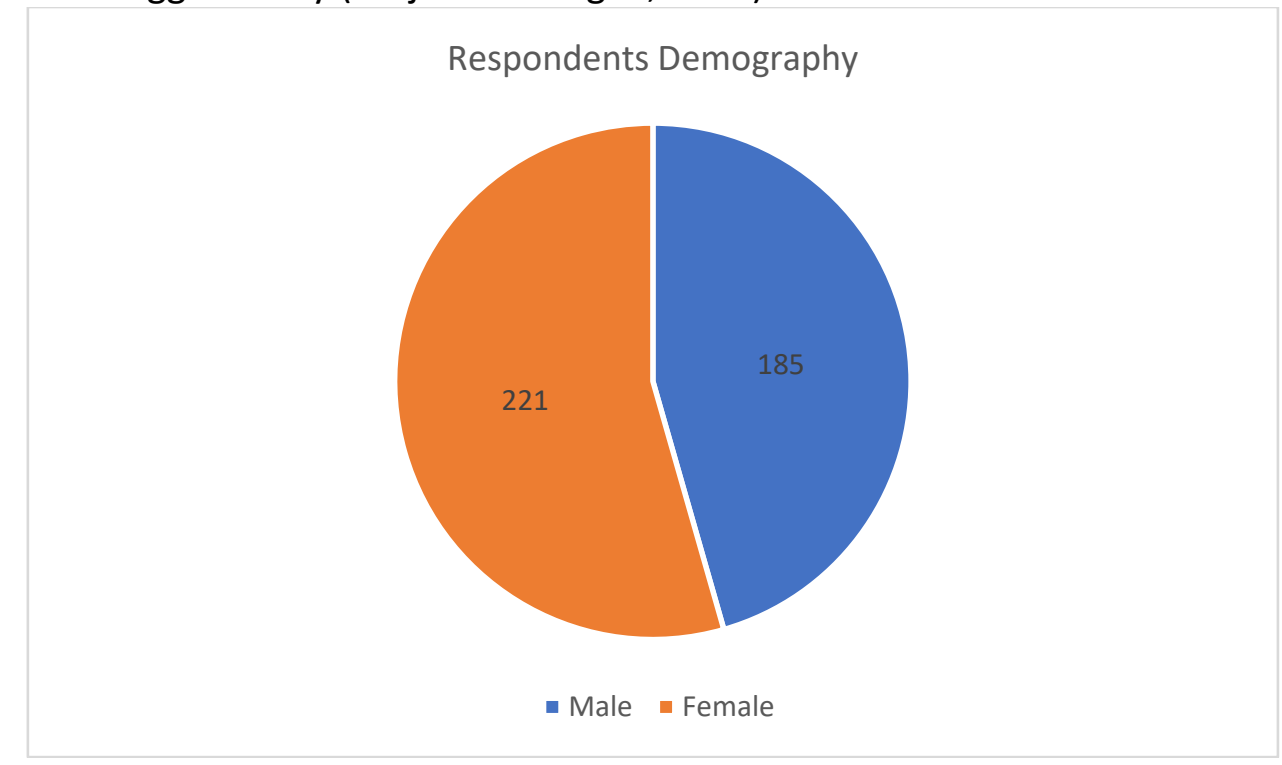

Figure 6 Respondents by Gender 


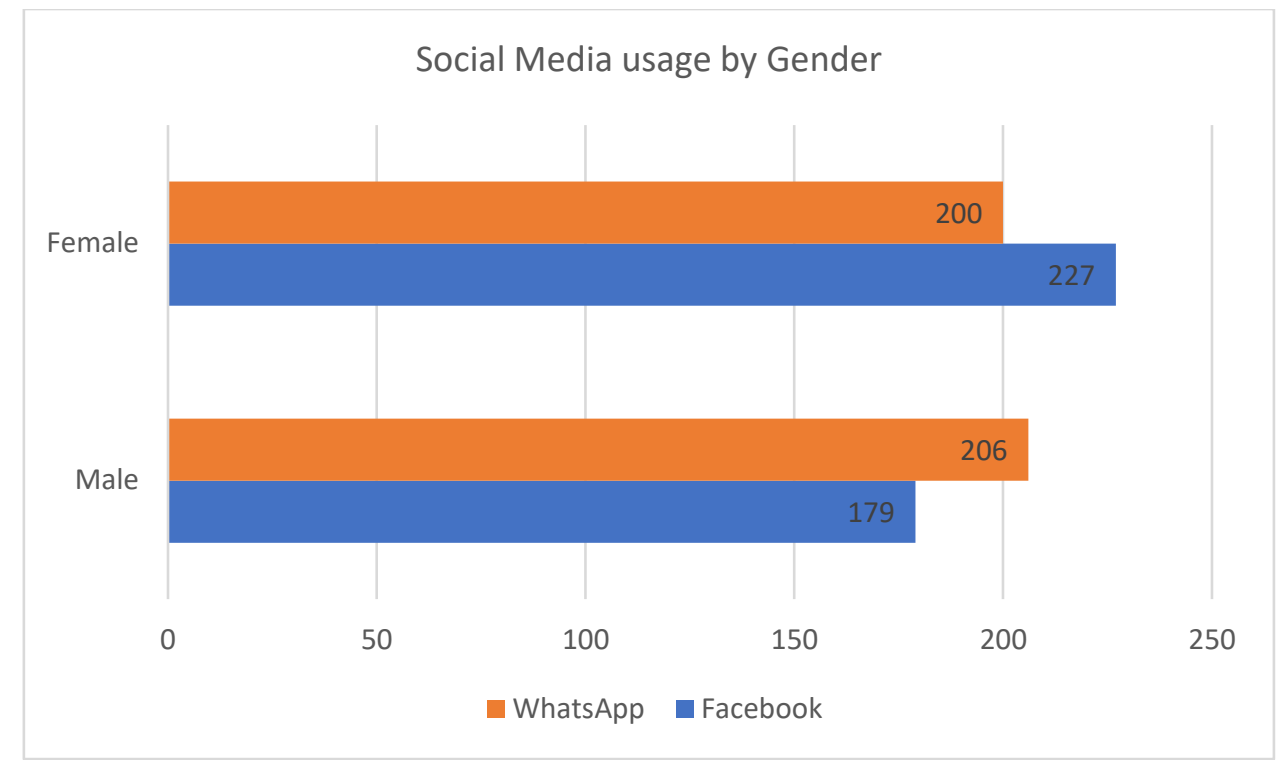

Figure 7 Forms of Social Media Usage

On the questions of the purpose of using WhatsApp, most respondents agreed that they use WhatsApp for their political discussion, for works related usage, and also for family matters. The respondents also somewhat used WhatsApp for social communication and least use it for business purposes. It is confirmed that WhatsApp has become the premier tool for political marketing, especially in Malaysia. This finding is parallel with the previous opinion and findings (Clayton, 2020; Farooq, 2018; Nizah \& Bakar, 2019; Tan, 2018). Figure 8 showed the data from the study.

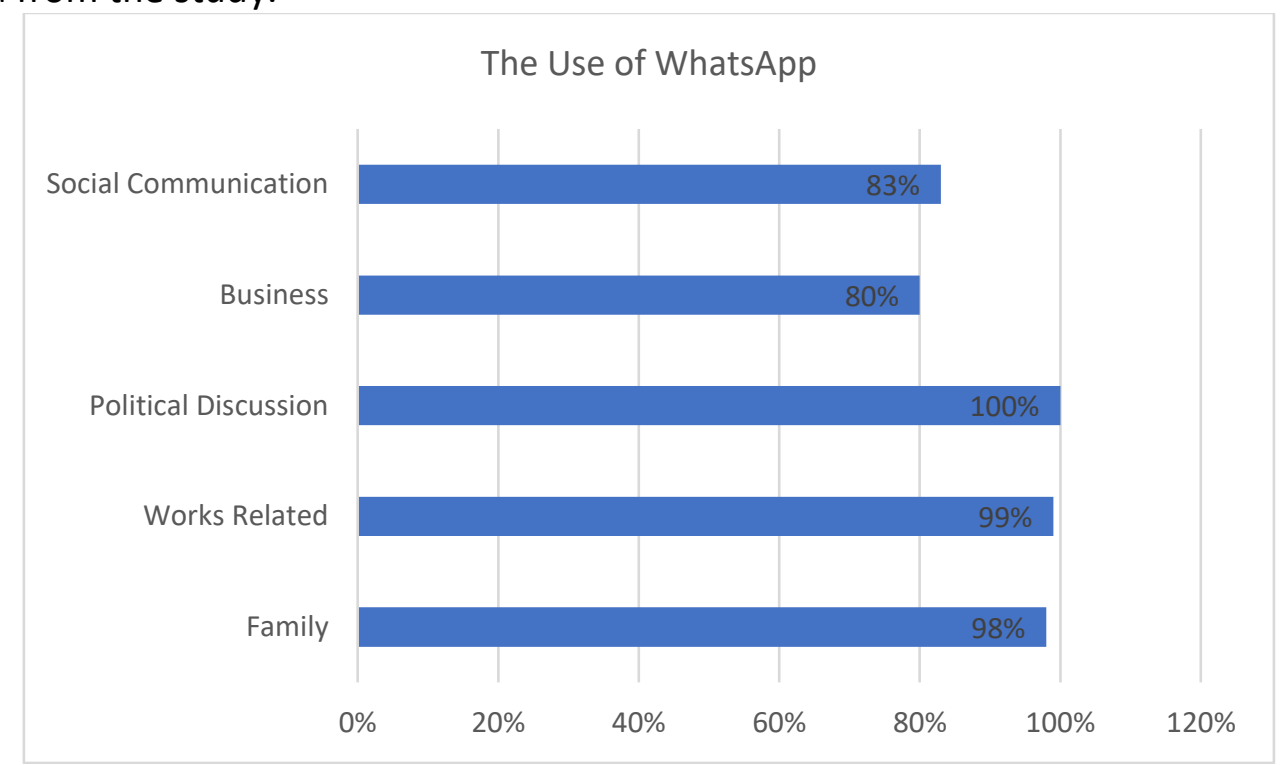

Figure 8 The Purpose of WhatsApp Usage

In terms of frequency use of WhatsApp, it shows a high percentage usage by the respondents either hourly, daily, or weekly. Therefore, it can assume that respondents did rely on WhatsApp in their daily uses, and that use is more on political discussion, work-related activities, and family discussion. 


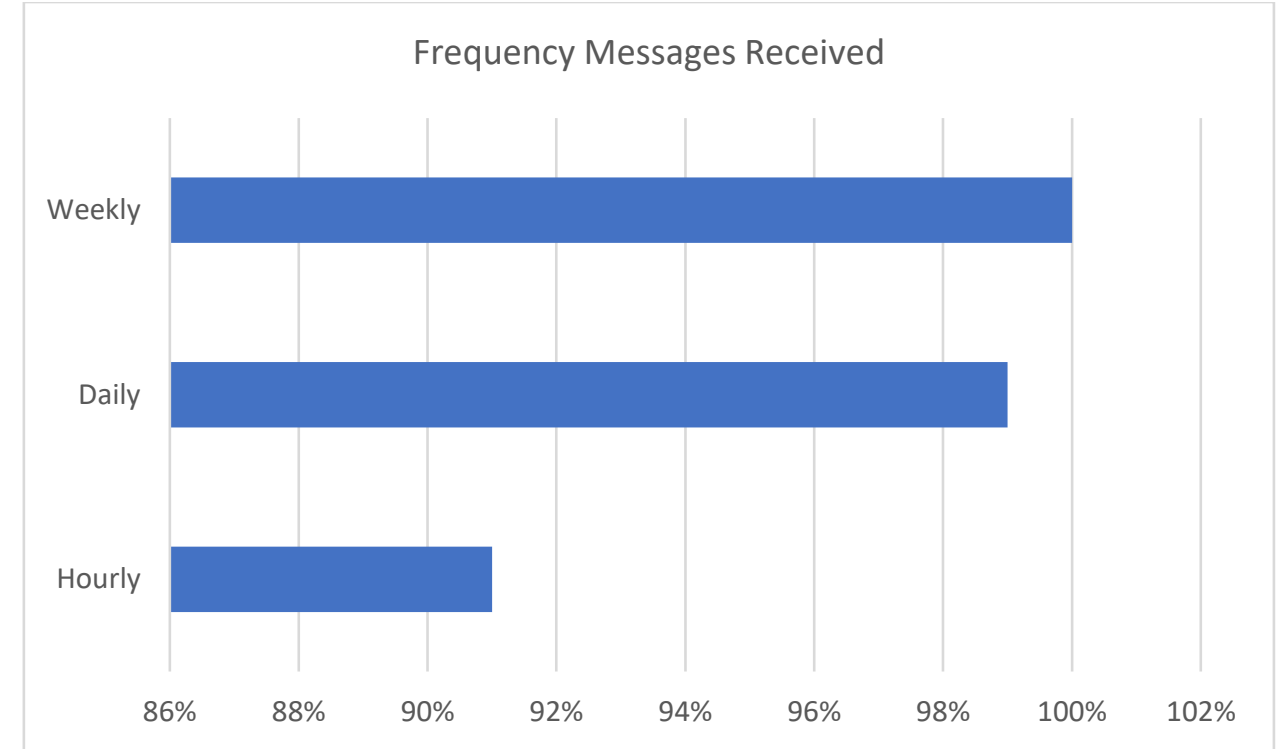

Figure 9 Frequencies of WhatsApp Usage

\section{Conclusion}

Social Media in Malaysia has been an important tool used by the political parties and politicians in disseminating the views on many political issues since the 2008 general elections. Furthermore, it is also increasingly popular and emerging as an important information source among the public. The Malaysia 14th General Election (GE14) is the vantage point for Malaysia's political history when Barisan Nasional lost their political supremacy. But that was also open a pandora box for a gridlock democracy as the party started losing feet for voters. By the next 15th general election, an increase of huge numbers of new voters especially among the young voters will be given another acid test for all political parties as reducing voters age has been approved (Nizah, Bakar, \& Azzis, 2020). The youths will be more skeptical of the new media but the new media can be their medium to engage more with the government. WhatsApp has been the main tool in political discussion, surpasses other social media forms. A thing for sure, that social media is now a way forward for political parties in strategizing their presence, concerns, anticipation, or even misled potential voters. Social media still will become a hit and become a major role in promoting political marketing agenda especially from the new young voters in Malaysia in the next coming 15th general election. From the theoretical point of view, this study highlights the sociological, psychological, and political power of WhatsApp in marketing tools. It also found that WhatsApp is largely influenced by its daily use. The exponential power of microblogging, such as WhatsApp and Telegram is expected to increase soon, especially in the forthcoming $15^{\text {th }}$ Malaysian General Election. Future studies should focus on how to handle fake news, or organizing micro-political blogging, and discover political play using technology that benefits the people specifically.

\section{References}

Abdullah, N., \& Anuar, A. (2018). Old Politics and New Media: Social Media and Malaysia's 2018 Elections. Retrieved August 3, 2021, from The Diplomat website: https://thediplomat.com/2018/05/old-politics-and-new-media-social-media-andmalaysias-2018-elections/

Al-Deen, H. S. N., \& Hendricks, J. A. (2012). Social Media: Usage and Impact. Lexington Books. 
Azhar, A. (2013). 'Social media crucial in election campaign' | Free Malaysia Today. Retrieved May 28, 2018, from Free Malaysia Today website:

http://www.freemalaysiatoday.com/category/nation/2013/04/19/social-media-crucialin-election-campaign/

Audit Bureau of Circulations Malaysia. (2017). Latest Audit Reports - July to December 2017 | ABCM. Retrieved May 28, 2018, from http://abcm.org.my/report/latest-audit-reportsjuly-to-december-2017/

Bernama. (2013). Malaysian Communications And Multimedia Commission (MCMC) I Suruhanjaya Komunikasi dan Multimedia Malaysia (SKMM) - MCMC To Monitor, Control Use Of Social Media In General Election 13 To Prevent Abuse. Retrieved June 12, 2018, from Bernama website: https://www.mcmc.gov.my/media/press-clippings/mcmc-tomonitor,-control-use-of-social-media-in-ge

Boczkowski, P. J., \& Papacharissi, Z. (Eds.). (2018). Trump and the Media. Massachusetts: The MIT Press.

Chang, P. K., \& Tham, J. S. (2016). Media Usage Patterns among Chinese Voters: In Preparation for the 14th Malaysian General Election (GE14). Asian Social Science, 12(12), 251. https://doi.org/10.5539/ass.v12n12p251

Chinnasamy, S. (2018). A Facebook election year? New Straits Times. Retrieved from https://www.nst.com.my/opinion/columnists/2018/02/339743/facebook-election-year

Chinnasamy, S., \& Abdul, N. (2018). Social media as political hatred mode in Malaysia's 2018 General Election. 02005. https://doi.org/10.1051/shsconf/20185302005

Chu, M. M. (2018). Big data and the big day: Tech's effect on GE14 - Nation | The Star Online. The Star Online. Retrieved from https://www.thestar.com.my/news/nation/2018/05/09/big-data-and-the-big-daytechs-effect-on-ge14/

Chun, S. A., \& Cho, J.-S. (2012). E-participation and transparent policy decision making. Information Polity, 17(2), 129-145. https://doi.org/10.3233/IP-2012-0273

Clayton, J. (2020). Misinformation About 2020 Election Spread Via WhatsApp, Targeted Spanish-Speaking Voters. Texas Public Radio. Retrieved from https://www.tpr.org/government-politics/2020-11-22/misinformation-about-2020election-spread-via-whatsapp-targeted-spanish-speaking-voters

Dave, P. (2020). Fake news spread on WhatsApp to Indian Americans plays stealth role in U.S. election. Reuters. Retrieved from https://www.reuters.com/article/usa-electionwhatsapp-idUSKBN27C19Q

Kasmani, F. M., Sabran, R., \& Ramle, A. N. (2014). Who Is Tweeting on \#PRU13? Asian Social Science, 10(18). https://doi.org/10.5539/ass.v10n18p144

Farooq, G. (2018). Politics of fake news: How WhatsApp became a potent propaganda tool in India. Media Watch, 9(1), 106-117. https://doi.org/10.15655/mw/2018/v9i1/49279

Gibson, R., \& Cantijoch, M. (2013). Conceptualizing and measuring participation in the age of the internet: Is online political engagement really different to offline? Journal of Politics, 75(3), 701-716. https://doi.org/10.1017/S0022381613000431

Gilardi, F., Gessler, T., Kubli, M., \& Müller, S. (2021). Social Media and Political Agenda Setting. Political Communication, 00(00), 1-22.

https://doi.org/10.1080/10584609.2021.1910390

Gomez, J. (2014). Social Media Impact on Malaysia's 13th General Election. Asia Pacific Media Educator, 24(1), 95-105. https://doi.org/10.1177/1326365X14539213

Grönlund, Å., \& Wakabi, W. (2015). Citizens' use of new media in authoritarian regimes: A 
case study of Uganda. Electronic Journal of Information Systems in Developing Countries, 67(1), 1-23. https://doi.org/10.1002/j.1681-4835.2015.tb00479.x

GSMArena.com. (2019). Samsung remains the top smartphone manufacturer in Q2 2019, Huawei and Apple follow. Retrieved November 20, 2019, from https://www.gsmarena.com/samsung_remains_the_top_smartphone_manufacturer_h uawei_and_apple_follow-news-38428.php

Hamid, N. N. B. A., \& Rahman, S. A. (2018). Impact of Social Media on Malaysia's Election Landscape. International Journal of Academic Research in Business and Social Sciences, 8(9), 275-284. https://doi.org/10.6007/IJARBSS/v8-i9/4590

Hyun, K. D. (2012). Americanization of web-based political communication? A comparative analysis of political blogospheres in the United States, the United Kingdom, and Germany. Journalism and Mass Communication Quarterly, 89(3), 397-413. https://doi.org/10.1177/1077699012447919

Internetworldstats.com. (2021). Asia Internet Stats by Country and 2021 Population Statistics. Retrieved July 28, 2021, from https://www.internetworldstats.com/asia.htm\#my

Jost, J. T., Barberá, P., Bonneau, R., Langer, M., Metzger, M., Nagler, J., ... Tucker, J. A. (2018). How Social Media Facilitates Political Protest: Information, Motivation, and Social Networks. Advances in Political Psychology, 39(Suppl. 1), 85-118. https://doi.org/10.1111/pops.12478

Krejcie, R. V., \& Morgan, D. W. (1970). Determining Sample Size For Research Activities. Educational and Psychological Measurement, 38, 607-610.

Larsson, A. O., \& Moe, H. (2012). Studying political microblogging: Twitter users in the 2010 Swedish election campaign. New Media and Society, 14(5), 729-747. https://doi.org/10.1177/1461444811422894

Ho, L. K. (2012). Marketing Politicians On Facebook: An Examination Of The Singapore General Election 2011. Studies in Business and Economics, 7(1), 101-109. Retrieved from http://ideas.repec.org/a/blg/journl/v7y2012i1p101109.html\%5Cnhttp://eccsf.ulbsibiu.ro/RePEc/blg/journl/7110leng.pdf

Lim, Y. (2013). PM: GE13 will be Malaysia's 1st 'social media election' - Nation | The Star Online. Retrieved June 12, 2018, from The Star Online website: https://www.thestar.com.my/news/nation/2013/02/27/pm-ge13-will-be-malaysias1st-social-media-election/

Malay Mail. (2013). Putrajaya blew over RM500m on pre-polls ad offensive | Malaysia | Malay Mail. Retrieved June 13, 2018, from Malay Mail website: https://www.malaymail.com/s/509841/putrajaya-blew-over-rm500m-on-pre-polls-adoffensive

Malaysian Communications and Multimedia Commission. (2017). Internet Users Survey 2017. Cyberjaya.

Malaysian Communications and Multimedia Commission. (2020). Internet Users Survey 2020. In The Internet Users Survey. https://doi.org/1823-2523

Mohamad, M. (2008). Malaysia - democracy and the end of ethnic politics? Australian Journal of International Affairs, 62(4), 441-459. https://doi.org/10.1080/10357710802480691

Miller, N. W., \& Ko, R. S. (2015). Studying political microblogging: Parliamentary candidates on twitter during the February 2012 election in Kuwait. International Journal of Communication, 9(1), 2933-2953.

Miniwatts Marketing Group. (2018). Asia Internet Stats by Country and 2018 Population 
Statistics. Retrieved May 25, 2018, from Internet World Stats website: https://www.internetworldstats.com/asia.htm\#my

Mobilesquared. (2019). WhatsApp users by country for 200 active markets. Retrieved July 28, 2021, from WhatsApp Users by Country website:

https://mobilesquared.co.uk/whatsapp-users-by-country/

Müller, J. (2021). Smartphone users in Malaysia 2017-2025. Retrieved July 28, 2021, from Smartphone users in Malaysia 2015-2025 website:

https://www.statista.com/statistics/494587/smartphone-users-in-malaysia/

Muniandy, L., \& Muniandy, B. (2013). The Impact of Social Media in Social and Political Aspects in Malaysia : An Overview. International Jurnal of Humanities and Social Science, 3(11), 71-76.

Newman, N., Fletcher, R., Kalogeropoulos, A., A.L.Levy, D., \& Nielsen, R. K. (2017). Reuters Institute Digital News Report 2017. In Digital News Report 2017.

https://doi.org/10.1080/21670811.2012.744561

Newman, N., Fletcher, R., Schulz, A., Andi, S., Robertson, C. T., \& Nielsen, R. K. (2021). Reuters Institute Digital News Report 2021. In Reuters Institute Digital News Report 2021.

Nizah, M. A. M., \& Bakar, A. R. A. (2019). WhatsApp Election in Malaysia: Assessing the Impact of Instant Messaging on Malaysia's 14th General Election. International Journal of Academic Research in Business and Social Sciences, 9(3).

https://doi.org/10.6007/ijarbss/v9-i3/5643

Nizah, M. A. M., Bakar, A. R. A., \& Azzis, M. S. A. (2020). Undi 18 : The Psychology of Participation among Young Voters in Malaysia. UTAR Applied Psychology Reserach Conference 2020, 71800. Kampar: UTAR.

Pepinsky, T. B. (2013). The New Media and Malaysian Politics in Historical Perspective. Contemporary Southeast Asia, 35(1), 83. https://doi.org/10.1355/cs35-1d

Poell, T. (2019). Social media, temporality, and the legitimacy of protest. Social Movement Studies, 1-16. https://doi.org/10.1080/14742837.2019.1605287

Muhamad, R. (2015). Online Opposition and Elections in Malaysia. Asian Social Science, 11(10), 281-291. https://doi.org/10.5539/ass.v11n10p281

Salman, A., Salleh, M. A. M., Yusoff, M. A., \& Abdullah, M. Y. H. (2018). Political Engagement on Social Media as Antecedent for Political Support among Voters in Malaysia. Jurnal Komunikasi, Malaysian Journal, 34(2), 152-165.

Sani, M. A. M. (2014). The social media election in Malaysia: The 13th general election in 2013. Kajian Malaysia, 32(Supp. 2), 123-147.

Saodah Wok, \& Mohamed, S. (2017). Internet and Social Media in Malaysia: Development, Challenges and Potentials. The Evolution of Media Communication, (July). https://doi.org/10.5772/intechopen.68848

Shirley Li. (2014). Study: Facebook and Twitter Are No Place for Political Debate - The Atlantic. The Atlantic. Retrieved from

https://www.theatlantic.com/technology/archive/2014/08/study-facebook-andtwitter-are-no-place-for-political-debate/379256/

Statista Research Department. (2019). Smartphone users in Malaysia 2017-2023. Retrieved November 20, 2019, from https://www.statista.com/statistics/494587/smartphoneusers-in-malaysia/

Statista Research Department. (2021). WhatsApp - Statistics \& Facts. WhatsApp - Statistics \& Facts. Retrieved from https://www.statista.com/topics/2018/whatsapp/

Tan, T. (2018). It's shaping up to be a WhatsApp election - Nation | The Star Online. Retrieved 
May 28, 2018, from The Star Online website:

https://www.thestar.com.my/news/nation/2018/04/01/its-shaping-up-to-be-awhatsapp-election-platform-takes-over-from-social-media-in-dishing-out-politi/

The Star Online. (2018). Barisan Nasional still most popular among the poor - Nation I The Star Online. The Star Online. Retrieved from

https://www.thestar.com.my/news/nation/2018/08/12/barisan-nasional-still-mostpopular-among-the-poor/

Vicente, M. R., \& Novo, A. (2014). An empirical analysis of e-participation. The role of social networks and e-government over citizens' online engagement. Government Information Quarterly, 31(3), 379-387. https://doi.org/10.1016/j.giq.2013.12.006

Weiss, M. L. (2013). Parsing the Power of "New Media" in Malaysia. Journal of Contemporary Asia, 2336(July). https://doi.org/10.1080/00472336.2012.759332

Yusop, F. D., \& Sumari, M. (2013). The Use of Social Media Technologies among Malaysian Youth. Procedia - Social and Behavioral Sciences, 103(November), 1204-1209. https://doi.org/10.1016/j.foodpol.2016.11.002

Sulong, Z. (2017). BN in trouble with falling newspaper circulation, says editor | The Malaysian Insight. Retrieved May 28, 2018, from The Malaysian Insight website: https://www.themalaysianinsight.com/s/16502/

Zurairi, A. R. (2013). Spending soars as BN sets out to conquer ad space - Malaysia Today. Retrieved June 1, 2018, from The Malaysian Insider website: http://www.malaysiatoday.net/2013/04/10/spending-soars-as-bn-sets-out-to-conquer-ad-space/

Zurairi, A. R. (2018). TV now Malaysians' most trusted news source, study reveals | Malaysia I Malay Mail. Retrieved June 13, 2018, from Malay Mail website: https://www.malaymail.com/s/1581911/tv-now-malaysians-most-trusted-newssource-study-reveals 